DOI: 10.33184/dokbsu-2021.6.13

\title{
В БашГУ обсудили научное и педагогическое наследие профессора Рима Зайнигабитовича Янгузина
}

15 ноября 2021 года в Башкирском государственном университете состоялся круглый стол, посвященный памятной дате - 80-летию со дня рождения советского и российского этнографа, специалиста по проблемам этногенеза и этнической истории башкир, изучению их традиционного хозяйства и социальной структуры - доктора исторических наук, профессора Рима Зайнигабитовича Янгузина. Основные направления работы круглого стола были обращены к наследию Рима Янгузина как исследователя, педагога, организатора науки, а также осмыслению роли исторических источников в работе этнографа, этнографии как инструмента изучения традиционного хозяйственного уклада, языковым и культурным аспектам бытия этноса.

Открыли Круглый стол Амина Уразова, директор Института истории и государственного управления БашГУ, Регина Мухаметзянова-Дуггал, и.о. директора Института этнологических исследований им. Р. Г. Кузеева УФИЦ РАН, Айбулат Псянчин, директор Ордена Знак Почета Института истории, языка и литературы УФИЦ РАН, Марат Зулькарнаев, и.о. директора Национальной библиотеки им. А.-З. Валиди РБ.

Программа круглого стола была разделена на мемориальную и научную. В ходе его работы участники, ученики и коллеги Рима Янгузина обсудили основные вехи научнопедагогической карьеры ученого, его вклад в науку. Ильдар Габдрафиков, старший научный сотрудник отдела этнополитологии ИЭИ им. Р. Г. Кузеева УФИЦ РАН, Нурислам Калмантаев и Юлия Иликеева, доценты кафедр ИИГУ БашГУ, Фуат Сулейманов, доцент кафедры теории и истории государства и права факультета экономики и права Сибайского института БашГУ высказались о Риме Зайнигабитовиче как о педагоге, наставнике, одном из видных представителей башкирской этнографической школы.

Научную значимость исследований, вклад в открытие этнографического музея БашГУ отметили Булат Азнабаев, заведующий кафедрой истории РБ, археологии и этнографии ИИГУ, Урал Каримов, заместитель заведующего Музейным комплексом ИИГУ БашГУ, Фидаиль Шаяхметов, доцент кафедры зарубежной истории ИИГУ БашГУ, Гулькай Шагапова, доцент кафедры башкирского языка и литературы БГПУ им. М. Акмуллы и Зиля Хабибуллина, старший научный сотрудник отдела религиоведения ИЭИ им. Р. Г. Кузеева УФИЦ РАН.

Материалы выступлений будут опубликованы на страницах журналов «Вестник Башкирского университета» и «Доклады Башкирского университета». 